\title{
Influence of electric arc furnace slag on characterisation of the produced geopolymer composites
}

HISHAM M. M. KHATER - Housing and Building National Research Centre (HBNRC)

- hkhater4@yahoo.com

Érkezett: 2015. 07. 02. - Received: 02. 07. 2015. - http://dx.doi.org/10.14382/epitoanyag-jsbcm.2015.13

\section{Abstract}

Effect of various doses of electric arc furnace slag (EAFS) - a by-product of steelmaking recovered after the oxidizing process - along with water cooled slag and cement kiln dust for the evaluation of optimum ratio of the added EAFS was studied. Results showed that the compressive strength of geopolymer specimens increases with EAFS up to 50\% then decreases with further slag increase, giving an increased mechanical strength than the control by $7.94 \%, 23.9 \%, 80.8 \%$ and $17.8 \%$ at ages of 90 days and $9.49,32.03,89.68$ and $37.6 \%$ at 120 days for replacement by 10 , 25,50 and $75 \%$ of EAFS, respectively. It is noticed that the enhancement in strength increases with EAFS and with curing time; even the full replacement by EAFS leads to further strength gain more than $10 \%$ replacement.

Keywords: geopolymer, GGBFS, EAFS, alkali, activator.

\section{Introduction}

In 1978, Davidovits [1] introduced the word geopolymer to describe an alternative cementitious material which has ceramic-like properties. As opposed to OPC, the manufacture of aluminosilicate-based geopolymer does not consume high levels of energy. This geopolymer technology has the potential to reduce emissions by $80 \%$ [2] since high calcining temperature is not required. It also exhibits ceramic-like properties with superior resistance to elevated temperatures at fire. Geopolymer can be produced by combining a pozzolanic compound or aluminosilicate source material with highly alkaline solutions [3]. Geopolymer can be thought of as a new generation binder as a substitute for the calcium silicate hydrate which are essential component of Portland cement, whereas cement plants are reported to emit up to 1.5 billion tons of $\mathrm{CO}_{2}$ into the atmosphere annually $[4,5]$. Hence, environmental preservation has become a driving force behind the search for new sustainable and environmentally friendly composites to replace conventional concrete produced from ordinary Portland cement (OPC).

Geopolymer binders exhibit technological and ecological advantages in comparison with OPC, and the industrial use of geopolymer concretes in the production of high performance building materials is expanding [6]. Different alkaline solutions based on alkali metal hydroxides, carbonates and silicates have been used over the past decades for the production of alkaliactivated binders [7]. A strong dependence on the nature of the alkaline activator in the structural and mechanical development of these binders has been identified throughout the literature.

Ferrous slags may be divided into two broad classes: those arising from the smelting of ores and those formed during refining of iron into steel. The former is mainly blast furnace slag, which is produced in very large amounts in many developed countries as a by-product of the manufacture of iron in blast furnace. It results from the fusion of limestone flux with ash from coke, the siliceous and aluminous residue remaining after the reduction and separation of the iron from the ore. The production of iron and slag in a blast furnace involves a continuous, rather than batch process, with both materials being produced in molten, homogeneous states. Much of the iron and steel slag produced around the world are air-cooled slowly, leading to the formation of a crystalline product. However, if the molten slag is cooled rapidly, for example by quenching with water, a granular glassy material is produced. This material, if collected, dried and ground to sufficient fineness is known to have latent hydraulic properties [8].

It has been established that the main products of slag hydration are essentially the same as the principal product formed when OPC is hydrated $[9,10]$ that is, calcium silicate hydrate (C-S-H). The main factors known to influence the hydraulic activity of slag cement include chemical composition, glass content, and fineness, activator content, curing temperature and water/cementitious material ratio [11]. Ground granulated blast furnace slag (GGBS) has been used for decades as partial replacement material in concrete and has well established standards describing their use [11-14]

A more modern process involves the use of electric arc furnace such as that used by the Libyan Iron and Steel Company. The electric arc furnace is able to produce very precise alloys when compared to the older Bessemer and open-heart techniques. According to the technical bulletin produced by the Libyan Iron and Steel Company [15], the company produces sponge iron by the direct reduction of iron ore with locally produced natural gas. This sponge iron is subsequently converted into steel in an electric arc furnace, which uses an electric arc to heat the raw materials. In addition to the sponge iron, several other materials are added which includes; steel scrap, fluorspar, limestone and dolomite. The end product of the oxidation process is steel plus large quantities of slag. This type of steel slag is known to have similar composition to Portland cement clinker; having significant quantity of $\mathrm{C}_{2} \mathrm{~S}$ and $\mathrm{C}_{3} \mathrm{~S}$ [16]. This waste material is traditionally utilized for road bases and as aggregates in concrete production in many countries [17]. Its 
use as cement replacement material has also been established; however this is limited by a general lack of understanding of its hydration process and by its heterogeneity, coarseness and higher particle density $[18,19]$.

Cement kiln dust (CKD) on the other hand, is a by-pass of cement plant production that contains partially calcined materials with some hydraulic and cementitious properties. Due to the presence of certain chemical constituents (high alkali, chloride, and sulphate content), which may cause problems in kiln operation and cement performance, CKD usually cannot be returned into the feedstock and has to be discarded. Alkalis from CKD may activate the hydration of slag constituents creating a cementitious material in which the waste material deficiencies will be converted into benefits.

Khater [20] studied the effect of cement kiln dust on alkali activated slag and studied their resistance against sulphate attack; results indicates that use of $25 \%$ cement kiln dust to slag materials leads to good enhancement in geopolymer structure. Effect of cement kiln dust on activation of geopolymer composite containing phosphogypsum and fly ash results in very good enhancement in thermal stability up to $1200^{\circ} \mathrm{C}$ by using 10 and $20 \%$ phosphogypsum was also studied by Khater and Zedane [21].

Khater [22] also studied thermal and acid resistance of alkali activated slag geopolymer, the results illustrate that geopolymer materials prepared using alkali activated slag exhibit considerable changes in compressive strength with increasing firing temperature from $300-1000^{\circ} \mathrm{C}$ and possessing an enhancement in thermal stability as compared to concrete specimens. Replacement of GGBFS by $15 \%$ air cooled slag (ACS) resists thermal deterioration up to $1000^{\circ} \mathrm{C}$. It was suggested to be suitably applied in the refractory insulation applications as well as for production of concrete nuclear reactors. On the other hand, geopolymer mixes exhibit low stability upon subjecting to different concentration from the mix of nitric and hydrochloric acid in equal ratio (1:1).

The main target of this paper is to study the effect of addition of various doses of electric arc furnace slag on the expense of the added water cooled one at constant ratio of cement kiln dust (25\%) as elucidated from Khater [20], for getting the optimum ratio of electric arc furnace slag along with water cooled slag and study their effect on the mechanical and microstructural characteristics.

\section{Experimental procedures}

\subsection{Materials}

The materials, which used in this investigation, are ground granulated water cooled blast furnace slag (GGBFS), air cooled electric arc furnace slag sourced from Iron and Steel FactoryHelwan, Egypt, and cement kiln by-pass dust from Beni-Suef Cement Factory, Egypt. The chemical compositions of the starting raw materials are tabulated in Table 1. Slag is formed from the dominant content of $\mathrm{SiO}_{2}$ and $\mathrm{MnO}, \mathrm{Fe}_{3} \mathrm{O}_{4}, \mathrm{CaO}$, and $\mathrm{Al}_{2} \mathrm{O}_{3}$. This way the coefficient of basicity, defining the ratio of base to acid oxides in the slag, is a suitable indicator for the definition of the oxidative capacity of the slag $[23,24]$ :

$$
\text { Basicity Coefficient }=[\mathrm{CaO}+\mathrm{MgO}+\mathrm{MnO}+. . .] /\left[\mathrm{SiO}_{2}+\mathrm{Al}_{2} \mathrm{O}_{3}\right]
$$

The use of the term acid and base are of course not those employed in aqueous solutions: in the present context, bases are oxygen donors, e.g. $\mathrm{Ca}, \mathrm{Na}$ and $\mathrm{K}$, while acids, e.g. $\mathrm{S}$ and $\mathrm{Cr}$, both in their (VI) oxidation state, are oxygen acceptors. By following the above equation, the basicity of water cooled slag will be equal to 1.0 and basicity of electric arc furnace slag is 0.96; this indicates the increased oxidative capacity of EAFS than that of water cooled one.

The hydraulic modulus (HM) also is defined as [25]:

$\mathrm{HM}=\left(\mathrm{CaO}+\mathrm{MgO}+\mathrm{Al}_{2} \mathrm{O}_{3}\right) / \mathrm{SiO}_{2}$

It is suggested that the HM of the slag materials should exceed 1.40 to ensure sound hydration property, where the $\mathrm{HM}$ of water cooled slag is equal to 1.39 and that of electric arc furnace slag is equal to 5.02, where the last value reflects the better hydration properties of electric arc furnace slag and confirms the latent hydraulic properties of water cooled slag.

The mineralogical composition is represented in Fig. 1; where ground granulated blast furnace slag materials composed of amorphous materials and EAFS composed of hematite, mullite and calcite and minor content of quartz. Cement dust pattern depicts that it is composed of calcite and a minor content from halite and sylvite.

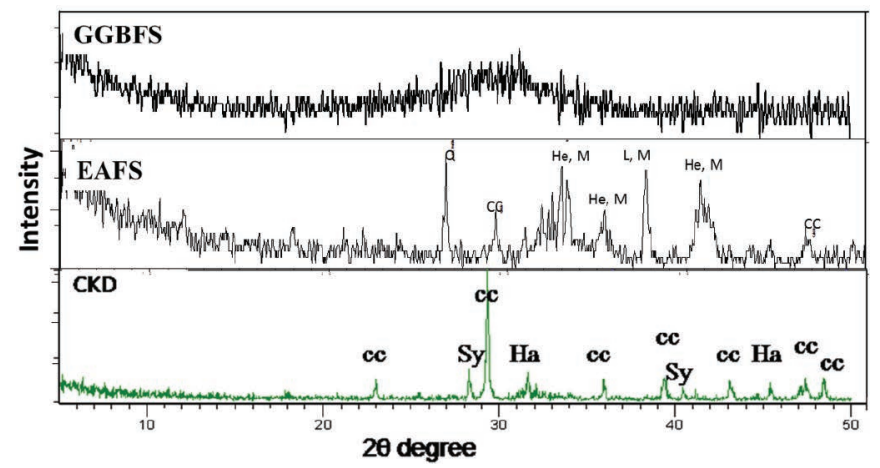

Fig. 1. Mineralogical composition of starting raw materials [Q: Quartz $\left(\mathrm{SiO}_{2}\right), \mathrm{CC}$ : Calcite $\left(\mathrm{CaCO}_{3}\right)$, Sy: Sylvite ( $\left.\mathrm{KCl}\right), \mathrm{Ha}$ : Halite ( $\left.\mathrm{NaCl}\right), \mathrm{He}$ : Hematite $\left(\mathrm{Fe}_{2} \mathrm{O}_{3}\right)$, M: Mullite (aluminum silicate)

1. ábra Kiindulási alapanyagok ásványos összetétele [Q: Kvarc $\left(\mathrm{SiO}_{2}\right), \mathrm{CC}$ : Kalcit $\left(\mathrm{CaCO}_{3}\right)$, Sy: Szilvit (KCl), Ha: Halit ( $\left.\mathrm{NaCl}\right), \mathrm{He}$ : Hematit $\left(\mathrm{Fe}_{2} \mathrm{O}_{3}\right), \mathrm{M}: \mathrm{Mullit}$ (alumino-szilikát)]

\begin{tabular}{|c|c|c|c|c|c|c|c|c|c|c|c|c|c|c|c|c|}
\hline Oxide content (\%) & $\mathrm{SiO}_{2}$ & $\mathrm{Al}_{2} \mathrm{O}_{3}$ & $\mathrm{Fe}_{2} \mathrm{O}_{3}$ & $\mathrm{CaO}$ & Mgo & $\mathrm{SO}_{3}$ & $\mathrm{~K}_{2} \mathrm{O}$ & $\mathrm{Na}_{2} \mathrm{O}$ & $\mathrm{TiO}_{2}$ & Mno & $\mathbf{P}_{2} \mathbf{O}_{5}$ & Cl- & Sro & $\mathrm{BaO}$ & L.O.I. & Total \\
\hline $\begin{array}{l}\text { Water -Cooled } \\
\text { Slag (GGBFS) }\end{array}$ & 36.67 & 10.31 & 0.50 & 38.82 & 1.70 & 2.17 & 1.03 & 0.48 & 0.57 & 4.04 & 0.04 & 0.05 & 0.18 & 3.28 & 0.12 & 99.96 \\
\hline $\begin{array}{l}\text { Electric arc furnace } \\
\text { slag (EAFS) }\end{array}$ & 8.20 & 0.73 & 38.89 & 39.52 & 0.88 & 0.24 & 0.34 & 0.25 & 0.22 & 8.14 & 2.20 & 0.02 & 0.03 & 0.13 & 0.11 & 99.90 \\
\hline $\begin{array}{l}\text { By-Pass Cement } \\
\text { Kiln Dust (CKD) }\end{array}$ & 8.29 & 2.84 & 2.07 & 51.90 & 0.57 & 2.09 & 3.42 & 2.63 & 0.14 & 0.13 & 0.13 & 6.120 & - & - & 19.59 & 99.90 \\
\hline
\end{tabular}

Table 1. Chemical composition of starting materials ( $m \%$ )

1. táblázat A kiindulási anyagok kémiai összetétele (m\%) 


\subsection{Experimental regime}

Geopolymer mixes were made by hand-mixing raw materials of each mixture passing a sieve of $90 \mu \mathrm{m}$ with the cement kiln dust for $10 \mathrm{~min}$ and a further $5 \mathrm{~min}$ with an electronic mixer as represented in Table 2. The water-binder ratio (w/b) was 0.34 by mass. The paste mixture was cast into $25 \times 25 \times 25 \mathrm{~mm}$ cubic-shaped moulds, vibrated for compaction and sealed with plastic sheet to minimize any loss of evaporable water.

\begin{tabular}{lcccccc}
$\begin{array}{l}\text { Mix } \\
\text { no. }\end{array}$ & $\begin{array}{c}\text { Water } \\
\text { cooled } \\
\text { slag } \\
\text { (GGBFS) }\end{array}$ & $\begin{array}{c}\text { Electric } \\
\text { arc furnace } \\
\text { slag } \\
\text { (EAFS) }\end{array}$ & $\begin{array}{c}\text { Cement } \\
\text { kiln } \\
\text { dust } \\
\text { (CKD) }\end{array}$ & $\begin{array}{c}\text { Total } \\
\mathbf{M}_{\mathbf{2}} \mathbf{O} / \\
\mathbf{A l}_{\mathbf{2}} \mathbf{O}_{\mathbf{3}}\end{array}$ & $\begin{array}{c}\mathbf{S i O}_{2} / \\
\mathbf{A l}_{2} \mathbf{O}_{\mathbf{3}}\end{array}$ & $\begin{array}{c}\text { Total } \\
\mathbf{M}_{\mathbf{2}} \mathbf{O} / \\
\mathbf{S i \mathbf { O } _ { 2 }}\end{array}$ \\
\hline Al & 90 & 10 & 25 & 0.45 & 3.57 & 0.08 \\
\hline A2 & 50 & 25 & 25 & 0.53 & 3.71 & 0.09 \\
\hline A3 & 25 & 50 & 25 & 0.80 & 4.20 & 0.12 \\
\hline A4 & 75 & - & 25 & 0.41 & 3.50 & 0.08 \\
\hline A5 & - & 75 & 25 & 2.08 & 6.54 & 0.20
\end{tabular}

Table 2. Composition of the geopolymer mixes ( $m \%)$ 2. táblázat Geopolimer keverékek összetétele ( $m \%)$

All mixes were left to cure undisturbed under ambient temperature for 24 hour then subjected to curing temperature of $40{ }^{\circ} \mathrm{C}$ with a $100 \%$ relative humidity. At the end of the curing regime, the specimens were subjected to the compressive strength measurements and then the resulted crushed specimens were exposed to stopping of the hydration process using stopping solution of alcohol/acetone (1:1) followed by washing with acetone as recommended by different investigators [26-28] to prevent further hydration and for further analysis followed by drying of the crushed specimens for $24 \mathrm{hr}$ at $80^{\circ} \mathrm{C}$, then preserved in a well tight container until the time of testing.

\subsection{Methods of investigation}

Chemical analysis was carried out using Axios, WD-XRF Sequential Spectrometer (Panalytical, Netherlands, 2009). Compressive strength tests were carried out using five tons German Brüf pressing machine with a loading rate of $100 \mathrm{~kg} / \mathrm{min}$ determined according to the ASTM [29]. The microstructure of the hardened alkali activated water cooled slag was studied using SEM Inspect S (FEI Company, Netherlands) equipped with an energy dispersive X-ray analyzer (EDX). The stopping of the progressed hydration was accomplished by subjecting the crushed samples to alcohol/acetone mix as recommended by different investigators $[26,27]$. Bonding characteristics of the alkali activated specimens were analyzed using a Nicolet-6700 Fourier transformed infrared spectrometer FTIR. Test sample was ground and uniformly mixed with $\mathrm{KBr}$ at a weight ratio $\mathrm{KBr}$ : specimen=200:1.The mixture, $0.20 \mathrm{~g}$ was pressed to a disk of $13 \mathrm{~mm}$ in diameter for analysis at $8 \mathrm{t} / \mathrm{cm}^{2}$. The wave number was ranging from 400 to $4000 \mathrm{~cm}^{-1}[20,30]$.

\section{Results and discussion}

\subsection{Effect of electric arc furnace slag on characteristics of the produced geopolymer}

FTIR spectra of 28 days cured $\left(40{ }^{\circ} \mathrm{C}\right.$ and $\left.100 \% \mathrm{RH}\right)$ geopolymer specimens having various cement dust content are shown in Fig. 2. Bands description are as follow: Stretching vibration of $\mathrm{O}-\mathrm{H}$ bond at about $3430,1600 \mathrm{~cm}^{-1}$, stretching vibration of $\mathrm{CO}_{2}$ located at about $1410 \mathrm{~cm}^{-1}$, asymmetric stretching vibration (T-O-Si) at about $975 \mathrm{~cm}^{-1}$ where $\mathrm{T}=\mathrm{Si}$ or $\mathrm{Al}$, symmetric stretching vibration of $\mathrm{CO}_{2}$ at about $870 \mathrm{~cm}^{-1}$, symmetric stretching vibration $(\mathrm{Si}-\mathrm{O}-\mathrm{Si})$ in the region 676 $700 \mathrm{~cm}^{-1}$ and bending vibration $(\mathrm{Si}-\mathrm{O}-\mathrm{Si}$ and $\mathrm{O}-\mathrm{Si}-\mathrm{O})$ in the region of $430-445 \mathrm{~cm}^{-1}$.

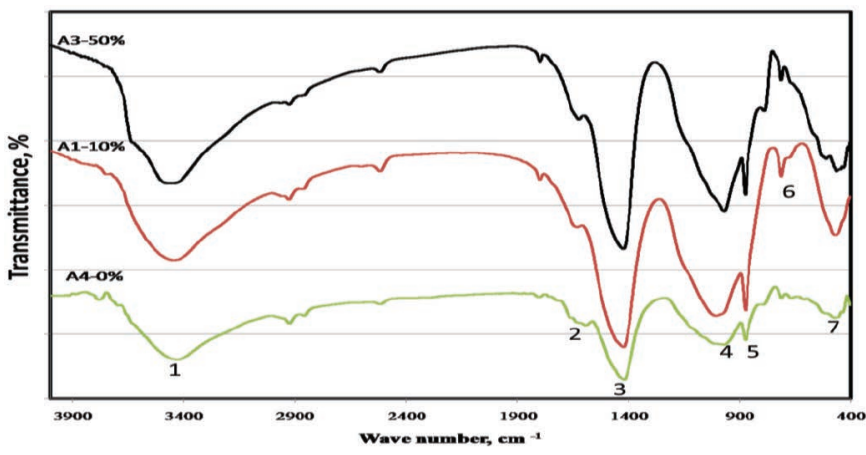

Fig. 2. FTIR spectra of 28days geopolymer specimens having various ratios of EAFS [1: Stretching vibration of $\mathrm{O}-\mathrm{H}$ bond, 2: Bending vibrations of $(\mathrm{HOH})$, 3: Stretching vibration of $\mathrm{CO}_{2}, 4$ : Asymmetric stretching vibration (T-O-Si), 5: Symmetric stretching vibration of $\mathrm{CO}_{2}$, 6: Symmetric stretching vibration ( $\mathrm{Si}-\mathrm{O}-\mathrm{Si}$ ), 7: Bending vibration (Si-O-Si and O-Si-O)]

2. ábra Különbözö mennyiségben EAFS adalékot tartalmazó geopolimer próbatestek FTIR spektrumai 28 napos korban [1: Vegyértékrezgés O-H kötés, 2: Deformációs rezgés (HOH), 3: Vegyértékrezgés $\mathrm{CO}_{2}, 4$ : Aszimmetrikus vegyértékrezgés (T-O-Si), 5: Szimmetrikus vegyértékrezgés $\mathrm{CO}_{2}$, 6: Szimmetrikus vegyértékrezgés ( $\mathrm{Si}-\mathrm{O}-\mathrm{Si}$ ), 7: Deformációs rezgés (Si-O-Si és O-Si-O)]

The pattern indicates the growth and the broadness of the main asymmetric band at about $975 \mathrm{~cm}^{-1}$ with EAFS increase up to $50 \%$ and shifted to a lower wave number values reflecting the increase in the vitreous content with EAFS addition, the increased intensity with EAFS indicates the growth of the amorphous content of N-A-S-H gel which has a positive effect on enhancement in the mechanical properties of the resulting structure, where the aluminosilicate polycondensation reactions promoted and increased with EAFS addition up to $50 \%$, resulting in growth of $\mathrm{N}-\mathrm{A}-\mathrm{S}-\mathrm{H}$ gel and the binding gels $(\mathrm{C}-(\mathrm{A})-\mathrm{S}-\mathrm{H}$ for slag. This is coherent with the increased intensity of hydration band at about 3400 and $1600 \mathrm{~cm}^{-1}$, where inclusion of EAFS, with its high hydraulic modulus as indicated from Eq. (2) and most specifically its role in supplying soluble $\mathrm{Ca}^{2+}$ ions, forming additional $\mathrm{CSH}$ phases in addition to N-A$\mathrm{S}-\mathrm{H}$ as well as $\mathrm{N}-(\mathrm{C})-\mathrm{A}-\mathrm{S}-\mathrm{H}$ leads extra strengthening of the matrix structure [31].

The increase in intensity of the $\mathrm{Si}-\mathrm{O}-(\mathrm{Si}, \mathrm{Al})$ asymmetric band in addition to the shift to higher wavenumber (from 690 to $779 \mathrm{~cm}^{-1}$ ) with increased contents of EAFS up to $50 \%$ suggests the modification of the aluminosilicate framework compared with solely GGBFS based geopolymers as a consequence of cation substitution in the non-framework sites [24]. The bending vibration band at about $430-445 \mathrm{~cm}^{-1}$ increases also with EAFS increase.

The appearance of bands in the regions of $1430 \mathrm{~cm}^{-1}(v \mathrm{C}-\mathrm{O})$, and $867 \mathrm{~cm}^{-1}(\delta \mathrm{C}-\mathrm{O})$ are typical of $\mathrm{CO}^{2-}$ vibrational groups, present in inorganic carbonates [32], the increased intensity of carbonate is mainly due to the carbonate in CKD and 
carbonation of the free alkalis lies within CKD, in addition to growth of carbonate with EAFS where the carbonates identified in this raw material do not react significantly under alkaline activation conditions [24].

The SEM microstructure of 90 days cured geopolymer specimens having 10 and 50\% EAF slag using 25\% CKD as an activator for geopolymerization reaction is shown in Fig. 4. The micrograph of $10 \%$ EAF slag (Fig. 3.a) indicates that the heterogeneity of the matrix with the dispersing of geopolymer plates within the structure in addition to calcium silicate hydrate that formed by the interaction of hydrated lime in CKD and free calcium ions in slag with dissolved silica forming $\mathrm{CSH}$ which increase the binding characteristics of three dimensional geopolymer structure. Further increase in the EAFS results in the increase of $\mathrm{CSH}$ and offers more nucleation sites for geopolymer formation leading to a homogeneous and hard structure [33], also the increased iron content with EAFS offers additional balancing cations for the three dimensional network forming more stable and homogeneous network [3, 34].
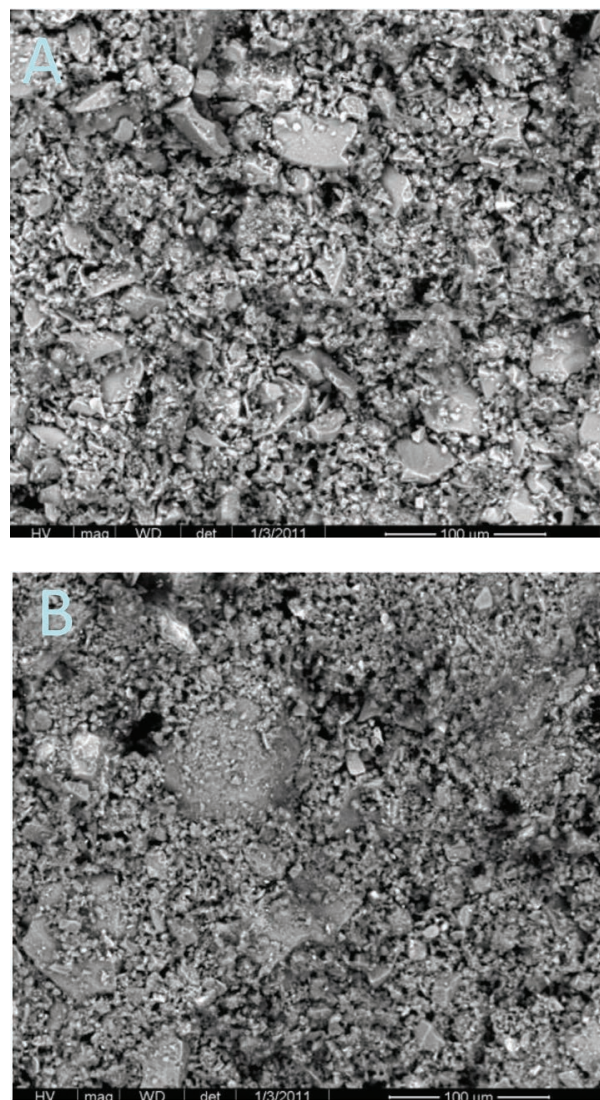

Fig. 3. SEM micrograph of 90 days alkali activated geopolymer specimens having (a) A1 containing $10 \%$ ACS, (b) A3 containing 50\% ACS

3. ábra Alkáli aktivált geopolimer minták elektronmikroszkópos képe 90 napos korban (a) A1 minta, 10\% ACS tartalom, (b) A3 minta, 50\% ACS tartalom

Fig. 4 shows the compressive strength of geopolymer mixes that were cured at $40{ }^{\circ} \mathrm{C}$ and $100 \% \mathrm{RH}$, up to 120 days using $25 \% \mathrm{CKD}$ as an activator for the reaction. It is known that the compressive strength of geopolymers is related to the degree of polymerization, which is strongly affected by the soluble silicates and aluminates of the geopolymeric system. The higher the degree of polymerization in the geopolymeric structure, the higher the obtained compressive strength.

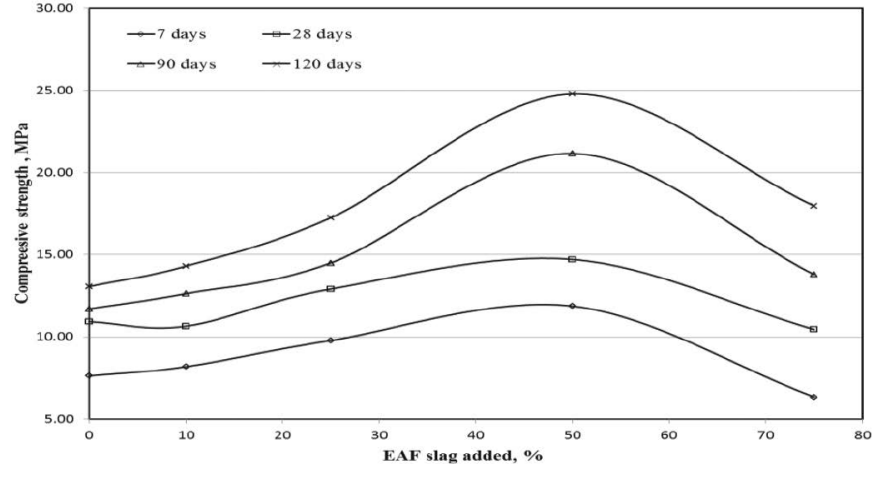

Fig. 4. Compressive strength of alkali activated slag geopolymer specimens using various ratios of EAFS

4. ábra Különböző mennyiségben EAFS adalékot tartalmazó geopolimer próbatestek nyomószilárdsága

It is found that the compressive strength of geopolymer specimens increase with EAFS up to $50 \%$ then decrease with further slag increase, giving an increased mechanical strength than the control by $7.94 \%, 23.9 \%, 80.8 \%$ and $17.8 \%$ at ages of 90 days and $9.49,32.03,89.68$ and $37.6 \%$ at 120 days for replacement by $10,25,50$ and $75 \%$ of EAFS, respectively. It is noticed that the enhancement in strength increases with EAFS with curing time; even the full replacement by EAFS leads to further strength gain more than $10 \%$ replacement.

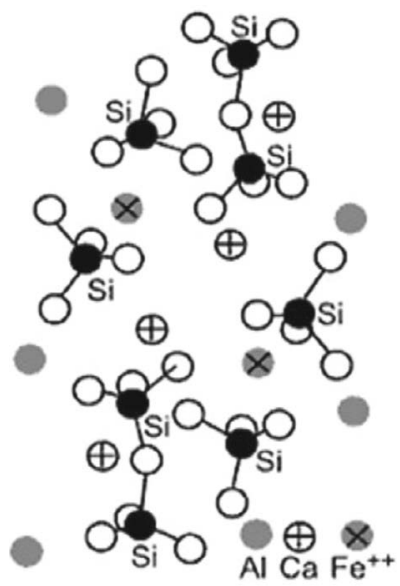

Fig. 5. Schematic structure of geopolymer skeleton charge balanced with calcium and iron cations

5. ábra Geopolimer váz sematikus szerkezete, kalcium és vas kationok töltésegyensúllyal

This can be explained by the high alkali content that lie within $\mathrm{CKD}$ and leads to the increase of $\mathrm{pH}$ of the medium and so the degree of polymerization of the resulting product, also EAFS is much harder than water cooled grains due to the high iron content as represented clearly in Table 1 . The effect of combination of $50 \%$ EAFS in addition to $25 \%$ GGBFS in a mix likely causes a higher strength since the anhydrous part of the EAFS contributes strongly to strength as compared to water cooled grains [35]. It is also likely that this is attributed to the fact that $\mathrm{Ca}^{2+}, \mathrm{Fe}^{3+}$ are capable of acting as charge-balancing cations within the geopolymeric binder structure $[3,34]$.

The efficiency of the EAFS geopolymer pastes were computed based on the equation proposed by Atis [36] for fly ash concrete. The equation was based on the normalization 
of the compressive strength of concrete with the quantity of cementitious materials. The equation for the same curing conditions and for the same water to binder ratio at specific curing age, is as follows:

$k=\frac{\left(\frac{f_{c}(t)_{f a}}{f_{c}(t)_{n p c}}-1\right)}{r_{f a}}+1$

Where, $k$ is the efficiency factor of EAFS, $c$ is the quantity of total cementitious binder (s), $f a$ is the quantity of EAFS, $r$ is the replacement ratio of EAFS (i.e., 0.3 for $30 \%, 0.5$ for $50 \%$ replacement), $f_{c}(t)_{n p}$ is the compressive strength of geopolymer mix containing any EAFS at time $t, f$ is compressive strength of EAFS at time t.

From Fig. 6, the efficiency factor of the geopolymer pastes increases gradually with the increase of the EAFS content up to $50 \%$ giving an efficiency value of $2.88 \%$ after 120 days, while decreases with $75 \%$ EAFS reaching the value of $2.36 \%$. This is coherent with the increased hydraulic modulus of EAFS $(\mathrm{HM}=5.02)$ than water cooled slag $(\mathrm{HM}=1.39)$ which positively increases the efficiency factor ratios as represented in Fig. 6, which in turn reflects the better hydration properties of electric arc furnace slag while confirms the latent hydraulic properties of water cooled slag. However, the basicity of water cooled slag which is equal to 1.0 and basicity of electric arc furnace slag is equal to 0.96; indicating the increased oxidative capacity of EAFS than that of water cooled slag.

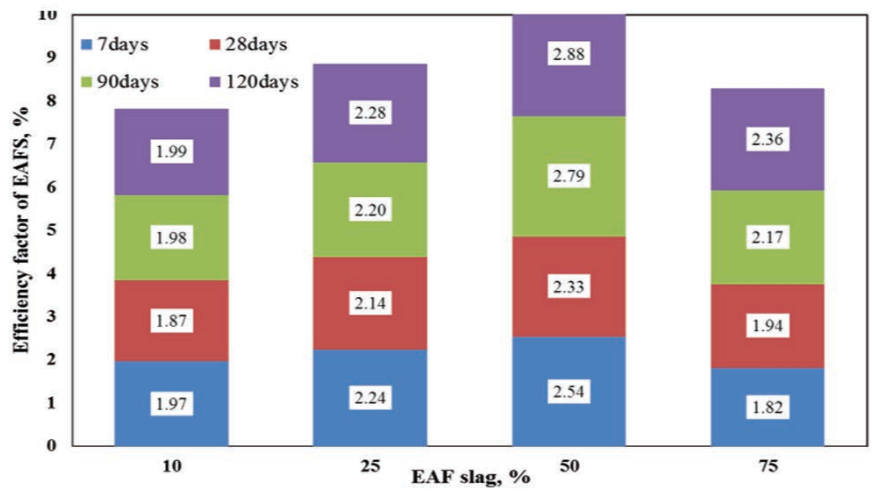

Fig. 6. Efficiency factor of alkali activated slag geopolymer specimens using various ratios of EAFS.

6. ábra Különbözö mennyiségben EAFS adalékot tartalmazó geopolimer próbatestek hatékonysági faktorai

A series of five $\mathrm{Na}(\mathrm{K})$-PSS polymer compositions were determined statistically from the oxide ratios of the five mixing geopolymer specimens as indicated in Table 2, where using $50 \%$ EAFS gives higher values of total $\mathrm{M}_{2} \mathrm{O} / \mathrm{Al}_{2} \mathrm{O}_{3}$, total $\mathrm{M}_{2} \mathrm{O}$ / $\mathrm{SiO}_{2}$ and $\mathrm{SiO}_{2} / \mathrm{Al}_{2} \mathrm{O}_{3}$ equal to $0.80,0.12$ and 4.20 , respectively, which ascribed to the strength increase with EAFS up to $50 \%$. It was suggested that the optimum range of oxide molar ratios $[37,38]: 0.2<\mathrm{M}_{2} \mathrm{O} / \mathrm{SiO}_{2}<0.48,3.3<\mathrm{SiO}_{2} / \mathrm{Al}_{2} \mathrm{O}_{3}<4.5$ resulting in three dimensional networks with a more branched structure and so homogeneous and compact structure formed.

A higher strength geopolymer is associated with a more desirable internal microstructure [39]. Mechanism of geopolymers involves the polycondensation reaction of geopolymeric precursors i.e. alumino-silicate oxide with alkali polysilicates yielding polymeric $\mathrm{Si}-\mathrm{O}-\mathrm{Al}$ bond [40-43].

$\mathrm{Mn}\left[-\left(\mathrm{Si}-\mathrm{O}_{2}\right)_{\mathrm{z}}-\mathrm{Al}-\mathrm{O}\right] \mathrm{n} \cdot \mathrm{wH}_{2} \mathrm{O}$

where $\mathrm{M}$ is the alkaline element, $\mathrm{z}$ is 1,2 or 3 and $\mathrm{n}$ is the degree of polycondensation [41]. Davidovits suggested that certain synthesis limits existed for the formation of strong products; satisfactory compositions lay in the range $\mathrm{M}_{2} \mathrm{O} / \mathrm{SiO}_{2}$, 0.2 to $0.48 ; \mathrm{SiO}_{2} / \mathrm{Al}_{2} \mathrm{O}_{3}, 3.3$ to $4.5 ; \mathrm{H}_{2} \mathrm{O} / \mathrm{M}_{2} \mathrm{O}, 10-25$; and $\mathrm{M}_{2} \mathrm{O} / \mathrm{Al}_{2} \mathrm{O}_{3}, 0.8$ to $1.6[40,42,43]$. The geopolymeric aluminosilicate has been grouped in three families depending on the atomic ratio $\mathrm{Si} / \mathrm{Al}$ that may be 1,2 or 3 [43]. Amorphous to semi-crystalline three dimensional alumino-silicate structures are of the poly(sialate) type $(\mathrm{Si}-\mathrm{O}-\mathrm{Al}-\mathrm{O}-)$, the poly(sialatesiloxo) type ( $\mathrm{Si}-\mathrm{O}-\mathrm{Al}-\mathrm{O}-\mathrm{Si}-\mathrm{O}-$ ), and the poly(sialatedisiloxo) type ( $\mathrm{Si}-\mathrm{O}-\mathrm{Al}-\mathrm{O}-\mathrm{Si}-\mathrm{O}-\mathrm{Si}-\mathrm{O}-)$ [40].

On the contrary, using $75 \%$ EAFS gives total $\mathrm{M}_{2} \mathrm{O} / \mathrm{Al}_{2} \mathrm{O}_{3}$, total $\mathrm{M}_{2} \mathrm{O} / \mathrm{SiO}_{2}$ and $\mathrm{SiO}_{2} / \mathrm{Al}_{2} \mathrm{O}_{3}$ equal to 2.08, 0.20 and 6.54, respectively, the increased previous ratios results in lowering in strength where the formed geopolymer structure is of two dimensional chains from poly-sialate disilioxy rather than the three dimensional network formed by using 50\% EAFS, in addition to the pessimum effect of the increased iron content as stated by Daux et al. [44] where, dissolution of aluminosilicate precursors containing significant levels of network-forming $\mathrm{Fe}^{3+}$ under slightly alkaline conditions, reprecipitation of dissolved Fe was much faster than the reprecipitation of Si and Al. It is therefore most likely that any reactive Fe present during geopolymerization behaves similarly, and reprecipitates very rapidly as hydroxide or oxyhydroxide phases and so lowers the alkali activator content necessary for the activation.

\section{Conclusions}

1. In the presence of $\mathrm{Ca}$ contained ingredients (slag) as a result of geopolymer coexistence and $\mathrm{C}-\mathrm{S}-\mathrm{H}$ phase and maximal geopolymer strength was reached.

2. Cement kiln dust has high alkalis content and free lime that can efficiently be utilized in the activation of industrial slag wastes results in the production of environmentally friendly cementing materials that can be applied in various building purposes.

3. Uses of electric arc furnace slag can be effectively used up to $50 \%$, while further increase leads to increase in the iron content that will precipitate as hydroxide and lower the medium alkalinity.

4. Using 50\% EAFS results in the growth of the amorphous content of N-A-S-H gel and the binding gels (C-(A)$\mathrm{S}-\mathrm{H}$ which has a positive effect on enhancement in the mechanical properties of the resulting structure.

5. The effect of combination of $50 \%$ EAFs in addition to $25 \%$ GGBFS in a mix as is likely to cause a higher strength values, also the $\mathrm{Ca}^{2+}, \mathrm{Fe}^{3+}$ are capable of acting as charge-balancing cations within the geopolymeric binder structure.

6. The compressive strength of geopolymer specimens increase with EAF slag up to 50\% then decrease with further slag increase, giving an increased mechanical strength than the control by $7.94 \%, 23.9 \%, 80.8 \%$ and 
$17.8 \%$ at ages of 90 days and $9.49,32.03,89.68$ and $37,6 \%$ at 120 days for replacement by $10,25,50$ and $75 \%$ of EAFS, respectively.

7. It is noticed the enhancement in strength increase with EAFS with curing time; even the full replacement by EAF slag leads to further strength gain more than $10 \%$ replacement.

8. The efficiency factor of the geopolymer pastes increases gradually with the increase of the EAF slag content up to $50 \%$ giving an efficiency value of $2.88 \%$ after 120 days, while decreases with $75 \%$ EAFS reaching the value of $2.36 \%$.

\section{References}

[1] Davidovits, J. (1991): Geopolymers: inorganic polymeric new materials. Journal of thermal analysis, Vol. 37, No. 8, pp. 1633-1656. http://dx.doi.org/10.1007/BF01912193

[2] Davidovits, J. (1993): Global warming impact on the cement and aggregates industries. World Resource Review, Vol. 6, No, 2, pp. 263-278.

[3] Davidovits, J. (1994): Properties of geopolymer cements. Proceedings First International Conference on Alkaline Cements and Concretes, Scientific Research Institute on Binders and Materials, Kiev State Technical University, Kiev, Ukraine, 1994, pp. 131-149.

[4] Malhotra, V. M. (2002): Introduction: sustainable development and concrete technology. ACI Concrete International, Vol. 24, No. 7, p. 22.

[5] Mehta, P. K. (2002): Greening of the concrete industry for sustainable development. ACI Concrete International,Vol. 24, No. 7, pp. 23-28.

[6] Van Deventer, J. S. J. - Provis, J. L. - Duxson, P. - Brice, D. G. (2010): Chemical research and climate change as drivers in the commercial adoption of alkali-activated materials. Waste and Biomass Valorization, Vol. 1, No. 1, pp. 145-155. http://dx.doi.org/10.1007/s12649-010-9015-9

[7] Provis, J. L. (2009): Activating solution chemistry for geopolymers. In: Provis, J.L., van Deventer, J.S.J. (eds.) Geopolymers: Structures,Processing, Properties and Industrial Applications, pp. 50-71. Woodhead Publishing, Abingdon

[8] Nwaubani, S.O. - Muntasser, T. Z. (2012): Hydration characteristics of cement pastes incorporating electric arc-furnace slag. Journal of Civil Engineering and Construction Technology, Vol. 3, No. 11, pp. 291-301. http://dx.doi.org/10.5897/JCECT12.043

[9] Muntasser, T. (2001): Properties and durability of slag based cement in the Mediterranean environment. PhD Thesis, Department of Civil Engineering. University of Surrey

[10] Neville, A. M. (1996): Properties of Concrete. Fourth Edition, John Wiley \& Sons. $844 \mathrm{p}$.

[11] ACI Committee 266 1R-87 (1987) Ground granulated blast-furnace slag as a cementitious constituent in concrete.

[12] Concrete Society (1991) The use of GGBS and PFA in concrete. Technical Report. Vol. 40, No. 142

[13] Sersale, R. - Amicarelli, V. - Frigione, G. - Ubbriaco, P. (1996): A study on the utilization of an Italian Steel Slag. Concresso Internacional de Quimica Do Cimento, Rio de Janeiro. pp. 194-198.

[14] Caijun, S. (2004): Steel Slag - Its production, processing, characteristics and cementitious properties. ASCE Journal of Materials in Civil Engineering, Vol. 16, No. 3, pp. 230-236. http://dx.doi.org/10.1061/(ASCE)0899-1561(2004)16:3(230)

[15] George, C. M. - Sorrentino, F. P. (1990): Valorization of basic oxygen steel slags. International Congress on the Chemistry of Cements. Paris, pp. 46-50.

[16] Libyan Iron and Steel Company (1998) Technical specification of products. Quality Control Department, Musrata, Libya.

[17] Manso, J. M. - Polanco, J. A. - Losañez, M. - Gonzalez, J. J. (2006): Durability of concrete made with EAF slag aggregates. Cement and Concrete Composites, Vol. 28, No. 6, pp. 528-534. http://dx.doi.org/10.1016/j.cemconcomp.2006.02.008

[18] Monshi, A. - Asgarani, M. K. (1999): Producing Portland cement from iron and steel slags and limestone. Cement and Concrete Research, Vol. 29, No. 9, pp. 1373-1377. http://dx.doi.org/10.1016/S0008-8846(99)00028-9
[19] Moosberg-Bustnes, H. - Lind, L. - Forrssberg, E. (2004): Fine particulate metallurgical by-products: An initial study of the influence on hydration and strength development. Scandinavian Journal of Metallurgy, Vol. 33, No. 1, pp. 15-21. http://dx.doi.org/10.1111/j.1600-0692.2004.00663.x

[20] Khater, H. M. (2013): Effect of cement kiln dust on Geopolymer composition and its resistance to sulphate attack. Green Materials, Vol. 1, No. 1, pp. 36-46. http://dx.doi.org/10.1680/gmat.12.00003

[21] Khater, H. M. - Zedane, S. R. (2012): Geopolymerization of Industrial ByProducts and Study of their Stability upon Firing Treatment. International Journal of Engineering and Technology, Vol. 2, No. 2, pp. 308-316.

[22] Khater, H. M. (2014): Studying the Effect of Thermal and Acid Exposure on Alkali Activated Slag Geopolymer. Advances in Cement Research, Vol. 26, No. 1, pp. 1-9. http://dx.doi.org/10.1680/adcr.11.00052

[23] Mitevska, N. (2000): The influence of technological parameters and the interface phenomena on the copper losses with the slag. Ph.D. Thesis, University of Belgrade, Bor, Serbia.

[24] Bernal, S. A. - Rodríguez, E. D. - Gutiérrez, R. M. - Provis, J. L. - Delvasto, S. (2012): Activation of Metakaolin/Slag Blends Using Alkaline Solutions Based on Chemically Modified Silica Fume and Rice Husk Ash. Waste and Biomass Valorization, Vol. 3, No. 1, pp. 99-108. http://dx.doi.org/10.1007/s12649-011-9093-3

[25] Chang, J. J. (2003): A study on the setting characteristics of sodium silicate-activated slag pastes. Cement and Concrete Research, Vol. 33, No. 7, pp. 1005- 1011. http://dx.doi.org/10.1016/S0008-8846(02)01096-7

[26] Saikia, N. - Usami, A. - Kato, S. - Kojima, T. (2004): Hydration behavior of ecocement in presence of metakaolin. Resource Progressing Journal; Vol. 51, pp. 35-41.

[27] Taha, A. S. - El-Didamony, H. - Abo El-Enein, S. A. - Amer, H. A. (1981): Physicochemical properties of supersulphated cement pastes. ZementKalk-Gips, Vol. 34, pp. 351-353.

[28] El-Sayed, H. A. - Abo El-Enein, S. A. - Khater, H. M. - Hasanein, S. A. (2011): Resistance of Alkali Activated Water Cooled Slag Geopolymer to Sulfate Attack. Ceramics - Silikáty, Vol. 55, No. 2, pp. 153-160. http://www.ceramics-silikaty.cz/2011/pdf/2011_02_153.pdf

[29] ASTM C109M-12 (2012) Standard Test Method for Compressive Strength of Hydraulic Cement Mortars. http://dx.doi.org/10.1520/C0109_C0109M

[30] Panias, D. - Giannopoulou, I. P. - Perraki, T. (2007): Effect of synthesis parameters on the mechanical properties of fly ash-based geopolymers. Colloids and Surfaces A: Physicochemical and Engineering Aspects, Vol. 301, No. 1-3, pp. 246-254. http://dx.doi.org/10.1016/j.colsurfa.2006.12.064

[31] Buchwald, A. - Tatarin, R. - Stephan, D. (2009): Reaction progress of alkaline-activated metakaolin-ground granulated blast furnace slag blends. Journal of Materials Science, Vol. 44, No. 20, pp. 5609-5617. http://dx.doi.org/10.1007/s10853-009-3790-3

[32] Garcia-Lodeiro, I. - Fernandez-Jimenez, A. - Palomo, A. - Macphee, D. E. (2010): Effect on fresh C-S-H gels of the simultaneous addition of alkali and aluminium. Cement and Concrete Research, Vol. 40, No. 1, pp. 27-32. http://dx.doi.org/10.1016/j.cemconres.2009.08.004

[33] Temuujin, J. - Van Riessen, A. - Williams, R. (2009): Influence of calcium compounds on the mechanical properties of fly ash geopolymer pastes. Journal of Hazardous Materials, Vol. 167, No. 1-3, pp. 82-88. http://dx.doi.org/10.1016/j.jhazmat.2008.12.121

[34] Davidovits, J. (1999): Geopolymer'99. Proceedings of the 2nd International Conference, 1999

[35] Heikal, M. - Radwan, M. M. - Morsy, M. S. (2004): Influence of curing temperature on the physicomechanical, characteristics of calcium aluminate cement with air cooled slag or water cooled slag. Ceramics Silikáty, Vol. 48, No. 4, pp. 185-196. http://www.ceramics-silikaty.cz/2004/pdf/2004_04_185.pdf

[36] Atis, C. D. (2005): Strength properties of high volume fly as roller compacted concrete and workable concrete and influence of curing condition. Cement and Concrete Research, Vol. 35, No. 6, pp. 1112-1121. http://dx.doi.org/10.1016/j.cemconres.2004.07.037

[37] Davidovits, J. (1982): Mineral Polymers and Methods of Making Them. US Patent 4,349,386

[38] Davidovits, J. (1999): Chemistry of Geopolymeric Systems Terminology. Proceedings of the 2nd International Conference, pp. 99-40. 
[39] Xu, H. - Van Deventer, J. S. J. (2002): Microstructural characterisation of geopolymers synthesised from kaolinite/stilbite mixtures using XRD, MAS-NMR, SEM/EDX, TEM/EDX, and HREM. Cement and Concrete Research, Vol. 32, No. 11, pp. 1705-1716.

http://dx.doi.org/10.1016/S0008-8846(02)00859-1

[40] Van Jaarsveld, J. G. S. - Van Deventer, J. S. J. - Lorenzen, L. (1997): The potential use of geopolymeric materials to immobilise toxic metals: Part I. Theory and applications. Minerals Engineering, Vol. 10, No. 7, pp. 659-669.

[41] Hardjito, D. - Wallah, S. E. 2 Sumajouw, D. M. J. 2 Rangan, B. V. (2004): Brief review of geopolymer concrete. Proceedings George Hoff Symposium, ACI, Las Vegas, USA

[42] Palomo, A. - Glasser, F. P. (1992): Chemically-bonded cementitious materials based on metakaolin. British Ceramic Transactions and Journal, Vol. 91, No. 4, pp. 107-112.

[43] Davidovits, J. - Davidovits, M. - Davidovits, N. (1994): Process for obtaining a geopolymeric alumino-silicate and products thus obtained. US Patent, 5,342,595

[44] Daux, V. - Guy, C. - Advocat, T. 2 Crovisier, J.-L. - Stille, P. (1997): Kinetic aspects of basaltic glass dissolution at $90{ }^{\circ} \mathrm{C}$ : role of aqueous silicon and aluminium. Chem. Geol., Vol. 142, No. 1-2, pp. 109-126. http://dx.doi.org/10.1016/S0009-2541(97)00079-X
Ref.:

Khater, Hisham M. M.: Influence of electric arc furnace slag on characterisation of the produced geopolymer composites Építóanyag - Journal of Silicate Based and Composite Materials, Vol. 67, No. 3 (2015), 82-88. p. http://dx.doi.org/10.14382/epitoanyag-jsbcm.2015.13

Elektrokemence salak hatása geopolimer kompozitok tulajdonságaira

A cikk bemutatja olyan geopolimerek tulajdonságainak vizsgálatait, amelyekben elektrokemence salak, vízzel hútött kohósalak és cement kemencehamu optimális arányát keresik. Az eredmények szerint a geopolimer nyomószilárdsága nô az elektrokemence salak 50\%-os adagolásáig. Megfigyelhetô, hogy az utókezelési idô növelésével az elektrokemence salakot tartalmazó geopolimerek nyomószilárdsága nô. A cement kemencehamu nagy alkáli-oxid és szabad mész tartalma hatékonyan segíti elô a geopolimerek hidratációját. Kulcsszavak: geopolimer, kohósalak, kemencesalak, alkáli aktiválás

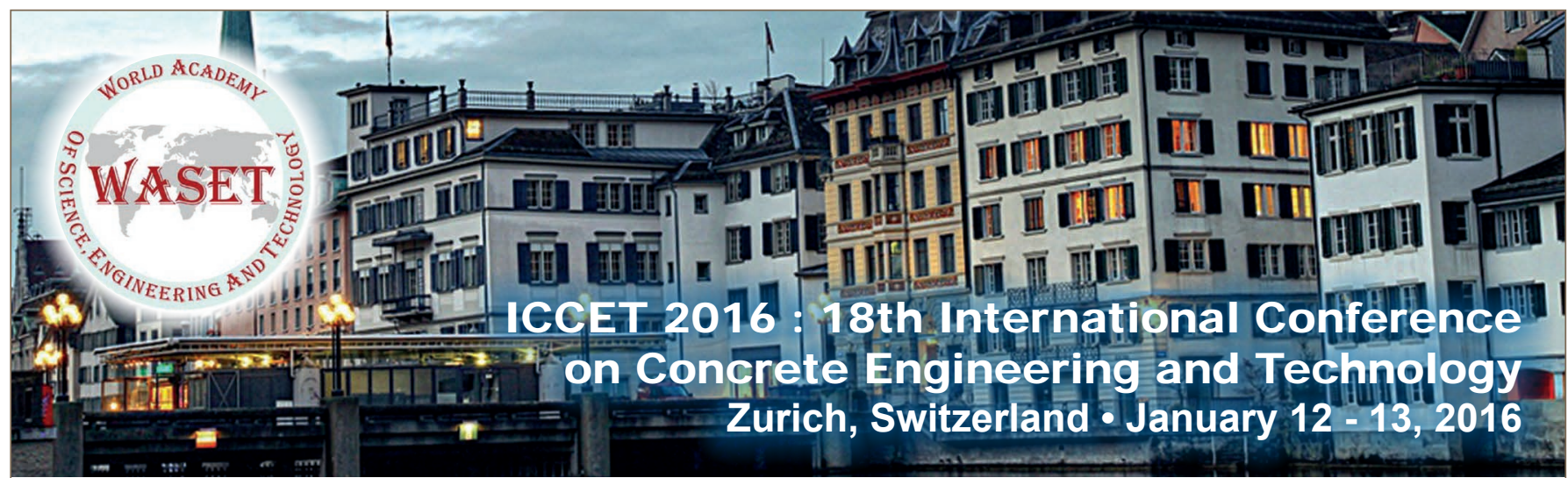

CONFERENCE OBJECTIVES

The ICCET 2016: 18th International Conference on Concrete Engineering and Technology aims to bring together leading academic scientists, researchers and research scholars to exchange and share their experiences and research results about all aspects of Concrete Engineering and Technology. It also provides the premier interdisciplinary forum for researchers, practitioners and educators to present and discuss the most recent innovations, trends, and concerns, practical challenges encountered and the solutions adopted in the field of Concrete Engineering and Technology.

\section{CALL FOR CONTRIBUTIONS}

All honourable authors are kindly encouraged to contribute to and help shape the conference through submissions of their research abstracts, papers and e-posters. Also, high quality research contributions describing original and unpublished results of conceptual, constructive, empirical, experimental, or theoretical work in all areas of Concrete Engineering and Technology are cordially invited for presentation at the conference. The conference solicits contributions of abstracts, papers and e-posters that address themes and topics of the conference, including figures, tables and references of novel research material.WASET

\section{CONFERENCE PROCEEDINGS}

All submitted conference papers will be blind peer reviewed by three competent reviewers. The post conference proceedings will be abstracted and indexed in the International Science Index , and submitted to be indexed in the Google Scholar, Scopus and Thomson Reuters. The conference abstracts and proceedings book, CD and certificate of presentation will be distributed to the conference participants at the conference registration desk.

\section{SPECIAL JOURNAL ISSUES}

ICCET 2016 has teamed up with the Special Journal Issue on Advances in Concrete Engineering and Technology. A number of selected highimpact full text papers will also be considered for the special journal issues. All submitted papers will have opportunities for consideration for this Special Journal Issue. The paper selection will be carried out during the peer review process as well as at the conference presentation stage. Submitted papers must not be under consideration by any other journal or publication. The final decision for paper selection will be made based on peer review reports by the Guest Editors and the Editor-in-Chief jointly. Selected full text papers will be online published as free of charge.

\section{IMPORTANT DATES}

Paper submissions

October 12, 2015

Notification of acceptance

Final paper submission and

authors' registration

October 20, 2015

Conference Dates

December 12, 2015

January 12 - 13, 2016

WWW.WASET.ORG/CONFERENCE/2016/01/ZURICH/ICCET 